\section{Research Square}

\title{
A new case of cutaneous melanocytoma harbouring the CRTC1-TRIM11 fusion: case report
}

Achraf Miry ( $\square$ achrafmiry@outlook.com )

Mohammed VI university hospital

\section{Asmae Aissaoui}

Mohammed VI University Hospital at Oujda: Centre Hospitalier Universitaire Mohammed VI - Oujda

\section{Samia Malki}

Mohammed VI University Hospital at Oujda: Centre Hospitalier Universitaire Mohammed VI - Oujda

\section{Youssef Bouhahyaoui}

El Farabi Hopsital

\section{Amal Bennani}

Mohammed VI University Hospital at Oujda: Centre Hospitalier Universitaire Mohammed VI - Oujda Ihssane Souaf

El Yosr pathology departement, Fes

Arnaud De La Fouchardière

Leon Berard Center

\section{Case Report}

Keywords: Clear cell sarcoma, CRTC1-TRIM11 fusion, Melanocytoma, Melanoma, Translocation

Posted Date: November 19th, 2020

DOl: https://doi.org/10.21203/rs.3.rs-108096/v1

License: (c) (1) This work is licensed under a Creative Commons Attribution 4.0 International License.

Read Full License 


\section{Abstract}

Background: The diagnosis of dermal primary and metastatic melanocytic tumors is often problematic. Recently, a new entity has been proposed, cutaneous melanocytoma with CRTC1-TRIM11 fusion (CMCT).

Case presentation: We report the $11^{\text {th }}$ case of cutaneous melanocytoma harbouring the CRTC1-TRIM11 fusion. The patient is a 35-year-old female patient, with no particular history, who presented in the dermatology department for a $1.5 \mathrm{~cm}$ nodular lesion on the dorsal aspect of the left foot. The lesion evolved for more than one year. She underwent tumour resection for clinical suspicion of malignant melanoma. Pathological examination of the resected specimen after H\&E stain revealed a dermal symmetrical proliferation made of spindle cells showing a melanocytic differentiation proved by expression of Melan A, S100 protein and SOX10. FISH study helped exclude a clear cell sarcoma. RNA sequencing showed the CRTC1-TRIM11 fusion.

Conclusions: Since only 11 cases have been documented, and because of the overlap with the clear cell sarcoma, the characterization of CMCT is still not fully satisfactory.

\section{Background}

The diagnosis of dermal primary and metastatic melanocytic tumors is often problematic.

Metastatic melanoma is the first diagnosis to consider in front of a dermal tumour expressing melanocytic markers. However, a primary melanocytic lesion should be considered in absence of a history of melanoma or a recognizable junctional component.

Primary dermal lesions that can simulate a melanoma include paraganglioma-like dermal melanocytic tumours, primary dermal melanoma and cutaneous clear cell sarcoma.

Both paraganglioma-like dermal melanocytic tumours and primary dermal melanoma are made of dermal atypical melanocytes, whereas cutaneous clear cell sarcoma presents in form of an unpigmented dermal tumor expressing various melanocytic differentiation markers by immunohistochemistry and is characterized by presence of EWSR1-ATF1 or EWSR1-CREB1 fusions.[1]

Recently, a new entity has been proposed, cutaneous melanocytoma with CRTC1-TRIM11 fusion (CMCT). However, since only 10 cases have been documented, and because of the overlap with the clear cell sarcoma, the characterization of CMCT is still not fully satisfactory. [2]

In our work, we report a case of a dense dermal nodule in 35 years old woman, with no particular history. The nodule is made of large unpigmented atypical cells displaying a melanocytic immunophenotype that harbored the CRTC1-TRIM11 fusion. [3]

\section{Case Presentation}


We report the case of a 35-year-old female patient, with no particular medical personal or family history. She presented in the dermatology department for a $1.5 \mathrm{~cm}$ nodular lesion on the dorsal aspect of the left foot. The lesion evolved for more than one year. (Fig. 1)

She underwent tumour resection for clinical suspicion of malignant melanoma. The resected specimen was received in our department for pathological examination. Microscopic examination after H\&E stain revealed a dermal symmetrical proliferation made of spindle cells. The nucleoli were prominent and the cytoplasm eosinophilic. There was no subcutaneous infiltration.

No melanoma in situ or squamous cell carcinoma in situ were observed. (Figs. 2, 3 and 4)

Although tumor cells contained no melanin pigments, a melanocytic differentiation was supported by expression of Melan A, S100 protein, SOX10. Other used antibodies included HMB45, P63, Cytokeratin $5 / 6$, CD 68 and P16, were not expressed by tumor cells. A proliferation index was as low as $20 \%$, was obtained by using the anti-Ki67 antibody. (Figs. 5, 6 and 7)

A study by FISH helped to rule out a clear cell sarcoma since its pathognomonic fusion was not detected.

A final diagnosis was obtained with help of results of the RNA sequencing showing a CRTC1-TRIM11 fusion, characteristic of the cutaneous melanocytoma.

\section{Discussion And Conclusions}

For many years, unclassified melanocytic tumors exist in the dermis and/or subcutaneous tissue, causing diagnostic problems. [2]

Among these tumors, cutaneous melanocytic tumor with consistent CRTC1-TRIM11 fusion is a rare dermal melanocytic tumor that has been very recently described.

Histologically, the proliferation is nodular and is made of nests and short fascicules of rounded and oval, or spindled cells. The cytoplasm is pale pink to vacuolated. The nucleus has open chromatin and prominent nucleolus.

There is no involvement of the epidermis, and the mitotic activity is variable.

The tumour is believed to present a borderline neoplasm since recurrence was recorded following complete excision in some reported cases $[2,4]$

These recurrence cases showed a similar histologic, immunophenotypic, and molecular features (CRTC1TRIM11 t $(19 ; 1)$ (p13; q42) fusion) for both primary and recurring lesion. These observations show the importance of following these patients.

Immunohistochemically, SOX10 should always be utilized when the diagnosis of a cutaneous melanocytic tumour with CRTC1-TRIM11 fusion is suspected. 
In one series, SOX10 was the only consistently positive marker. Immunoreactivity for S100 protein was variable, weak or focal (reported in half of cases). Reactivity for Melan-A and HMB45 is usually negative or focal. [5]

Complete excision of the tumour is the rule of treatment.

To date, only 10 cases of CMCTs harboring the CRTC1-TRIM11 fusion have been reported. (Table 1)

Table 1 Review of published cases of cutaneous melanocytoma with CRTC1-TRIM11 fusion 


\begin{tabular}{|c|c|c|c|c|c|c|c|c|c|}
\hline Case & Age & Sex & Location & Sox10 & $S 100$ & HMB45 & MelanA & $\begin{array}{l}\text { FISH } \\
\text { EWSR1 }\end{array}$ & $\begin{array}{l}\text { CRTC1- } \\
\text { TRIM11 } \\
\text { (by FICH } \\
\text { or RNA } \\
\text { Seq) }\end{array}$ \\
\hline 1 & 28 & $\mathrm{~F}$ & Leg & + & + & Focal & Focal & - & $\begin{array}{l}+(\text { RNA } \\
\text { seq and } \\
\text { FISH) }\end{array}$ \\
\hline 2 & 82 & $M$ & Lumbar & + & + & Focal & Focal & - & $\begin{array}{l}+(\text { RNA } \\
\text { seq and } \\
\text { FISH) }\end{array}$ \\
\hline 3 & 25 & $\mathrm{~F}$ & Elbow & + & Focal & - & Focal & NA & $\begin{array}{l}+(\text { RNA } \\
\text { seq and } \\
\text { FISH) }\end{array}$ \\
\hline 4 & 28 & $\mathrm{~F}$ & Tigh & + & + & Focal & Focal & - & $\begin{array}{l}+(\text { RNA } \\
\text { seq and } \\
\text { FISH) }\end{array}$ \\
\hline 5 & 64 & $M$ & Neck & + & + & Focal & - & - & $\begin{array}{l}+(\text { RNA } \\
\text { seq and } \\
\text { FISH) }\end{array}$ \\
\hline 6 & 28 & $\mathrm{~F}$ & Arm & + & + & Focal & + & NA & $\begin{array}{l}+ \text { (RNA } \\
\text { seq) }\end{array}$ \\
\hline 7 & 32 & $M$ & + & Focal & - & - & NA & - & $+(\mathrm{FISH})$ \\
\hline 8 & 59 & $\mathrm{~F}$ & Face & + & - & - & - & NA & $\begin{array}{l}+(\text { RNA } \\
\text { seq and } \\
\text { FISH) }\end{array}$ \\
\hline 9 & 11 & $\mathrm{~F}$ & $\begin{array}{l}\text { Lower } \\
\text { leg }\end{array}$ & + & - & Focal & Focal & - & $\begin{array}{l}+(\text { RNA } \\
\text { seq and } \\
\text { FISH) }\end{array}$ \\
\hline 10 & 49 & $M$ & Leg & + & Focal & - & - & - & $\begin{array}{l}+(\text { RNA } \\
\text { seq and } \\
\text { FISH) }\end{array}$ \\
\hline $\begin{array}{l}11 \\
\text { (Our } \\
\text { case) }\end{array}$ & 35 & $\mathrm{~F}$ & Foot & + & + & - & + & - & $\begin{array}{l}+(\text { RNA } \\
\text { seq) }\end{array}$ \\
\hline
\end{tabular}

\section{F: Female}

M: Male

NA: Not available

Seq: Sequencing 
In some case reports, the same CRTC1-TRIM11 fusion has been reported in clear cell sarcoma, emphasizing the theory that the new entity could be a cutaneous form of clear cell sarcoma with a novel fusion transcript and location limited to dermis, rather than a melanocytoma.

clear cell sarcoma (CCS) is the primary differential diagnosis of cutaneous melanocytoma. Distinction between the two entities is crucial since the clear cell sarcoma is know to give recurrences and metastases [9]

CCS manifests as a deeply localised lesion of the extremities in young adults, especially the foot.

As for cutaneous melanocytoma, CCS shows a nodular, well-circumscribed proliferation. Tumour cells are fusiform, with a pale eosinophilic cytoplasm. The nucleus is in a central position, is made of a vesicular chromatin and the nucleolus is prominent. Some cases show a variable degree of pigmentation and coexistence of giant cells. [7-9]

Some series has shown that CCS can overlap with cutaneous melanocytoma, and involve the dermis or even the epidermis and can therefore simulate a melanoma or a Spitz nevus.

In such cases, the diagnosis of CCS can be achieved by documenting the presence of rearrangements involving EWSR1, ATF1, or CREB1. [7-9]

In the literature, a significant difference in the immunohistochemical profiles has been reported, since in CCS, SOX10, S100 protein, Melan-A, and HMB45 are typically expressed [2,4,6-11]

Since the histological similarities between these two entities can be striking, Bontoux et al argue that CMTCT can be seen as a dermal variant of the clear cell sarcomas with a novel translocation. And because it is restricted to the dermis, it presents an improved clinical behaviour.

At the moment, it is thought that it is premature to classify CMTCT as a variant of CCS. It is agreed that some CCS of the skin with a strictly intradermal location are less prone to evolve into metastatic disease compared to deeper tumors. However, all described cases of dermal CCS had the expected EWSR1-ATF1 fusion. [7]

To fully classify the clinical and genomic features of cutaneous melanocytoma, additional studies are required

Other entities included in the differential diagnosis are dermal restricted melanocytic tumours.

The blue nevus family (The epithelioid blue nevus, the cellular blue nevus, and pigmented epithelioid melanocytomas) are dermal, frequently pigmented melanocytic proliferations.

In this family of tumours, one entity can be difficult to distinguish from cutaneous melanocytomas, amelanotic cellular blue nevi. However, it usually has a biphasic growth and strongly stains with HMB45. 
Metastatic melanoma should also be included in the differential diagnosis of cutaneous melanocytomas. However, the latter shows no activating RAF/RAS pathway mutations, TERT promoter mutations, and chromosomal gains and losses were not found. [12,13]

Other dermal spindle cells proliferations should be included in the differential diagnosis and have to be ruled out using morphological features, although in most instances an immunohistochemical study is necessary. These proliferations could be subdivided based on the architectural pattern (Tables 2 and 3 ) [14]

Table 2 Different dermal neoplasms based on their patterns

\begin{tabular}{|c|c|c|c|c|}
\hline $\begin{array}{l}\text { Fascicular } \\
\text { pattern }\end{array}$ & $\begin{array}{l}\text { Plexiform } \\
\text { pattern }\end{array}$ & Storiform pattern & $\begin{array}{l}\text { Biphasic } \\
\text { pattern }\end{array}$ & $\begin{array}{l}\text { Epithelial spindle } \\
\text { cell neoplasms }\end{array}$ \\
\hline $\begin{array}{l}\text { Nodular } \\
\text { fasciitis }\end{array}$ & $\begin{array}{c}\text { Nerve } \\
\text { sheath myxoma }\end{array}$ & - Dermatofibroma & Myofibroma & $\begin{array}{l}\text { - Desmoplastic } \\
\text { melanoma }\end{array}$ \\
\hline $\begin{array}{c}\text { Atypical } \\
\text { fibroxanthoma }\end{array}$ & $\begin{array}{c}\text { Cellular } \\
\text { neurothekeoma }\end{array}$ & 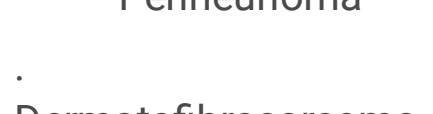 & & $\begin{array}{l}\text { Spindle cell } \\
\text { squamous cell }\end{array}$ \\
\hline leiomyoma & $\begin{array}{l}\text { Plexiform } \\
\text { schwannoma }\end{array}$ & $\begin{array}{l}\text { Dermatofibrosarcoma } \\
\text { protuberans }\end{array}$ & & \\
\hline $\begin{array}{l}\text { Kaposi } \\
\text { sarcoma }\end{array}$ & & & & \\
\hline \multicolumn{5}{|l|}{ Leiomyosarcoma } \\
\hline Angiosarcoma & & & & \\
\hline
\end{tabular}

Table 3. Helpful immunohistochemistry panel for distinguishing different dermal spindle cell proliferations 


\begin{tabular}{|c|c|c|c|c|c|}
\hline & Leiomyosarcoma & Angiosarcoma & $\begin{array}{l}\text { Atypical } \\
\text { fibroxanthoma }\end{array}$ & $\begin{array}{l}\text { Spindle } \\
\text { cell } \\
\text { SCC }\end{array}$ & $\begin{array}{l}\text { Desmoplastic } \\
\text { melanoma }\end{array}$ \\
\hline Desmin & + & - & - & - & $+/-$ \\
\hline SMA & + & - & $+/-$ & $+/-$ & - \\
\hline CD34 & - & + & - & - & - \\
\hline S100 protein & - & - & - & - & + \\
\hline $\begin{array}{l}\text { Endothelial } \\
\text { markers (CD31, } \\
\text { ERG) }\end{array}$ & - & + & - & - & - \\
\hline $\begin{array}{l}\text { Melanocytic } \\
\text { markers } \\
\text { (HMN45, Melan- } \\
\text { A) }\end{array}$ & - & - & - & - & $+/-$ \\
\hline $\begin{array}{l}\text { Epithelial } \\
\text { markers (CK, } \\
\text { EMA) }\end{array}$ & $+/-$ & $+/-$ & - & + & $+/-$ \\
\hline
\end{tabular}

SCC: Squamous cell carcinoma

\section{Abbreviations}

$\mathrm{F}$

Female

$\mathrm{M}$

Male

NA

Not available

SCC

Squamous cell carcinoma

Seq

Sequencing

\section{Declarations}

- Ethics approval and consent to participate:

Not applicable.

- Consent for publication:

A signed consent is obtained from the patient. 
- Availability of data and materials:

The datasets used and/or analysed during the current study are available from the corresponding author on reasonable request.

- Competing interest:

The authors declare that they have no competing interests

- Funding:

Not applicable

\section{- Authors' contributions:}

MA analyzed literature data regarding cases of perianal granular cell tumor.

RZ interpreted the patient data regarding anal granular cell tumor.

MA, BA and EH performed the histological examination and were a major contributor in writing the manuscript.

All authors read and approved the final manuscript.

\section{- Acknowledgements:}

Not applicable

\section{References}

1. Bowen $G M$, Chang $A E$, Lowe $L$, et al. Solitary melanoma confined to the dermal and/or subcutaneous tissue: evidence for revisiting the staging classification. Arch Dermatol. 2000;136:1397-1399.

2. Cellier L, Perron E, Pissaloux D et al. Cutaneous melanocytoma with CRTC1-TRIM11 fusion: Report of 5 cases resembling clear cell sarcoma. Am J Surg Pathol 2018; 42: 382-9.

3. Mentzel T, Reisshauer S, Rütten A, et al. Cutaneous clear cell myomelanocytic tumour: a new member of the growing family of perivascular epithelioid cell tumours (PEComas). Clinicopathological and immunohistochemical analysis of seven cases. Histopathology. 2005;46:498-504.

4. Bontoux C, Baroudjian B, Le Maignan C, et al. CRTC1-TRIM11 fusion in a case of metastatic clear cell sarcoma: are CRTC1-TRIM11 fusion-bearing tumors melanocytomas or clear cell sarcomas? Am J Surg Pathol. 2019 Jan 22;43:861-863

5. Ko, J. S., Wang, L., Billings, S. D., Pissaloux, D., Tirode, F., Berry, R., \& De La Fouchardiere, A. (2019). CRTC1-TRIM11 fusion defined melanocytic tumors: A series of four cases. Journal of Cutaneous Pathology, 46(11), 810-818. 
6. Bianchi G, Charoenlap C, Cocchi S, et al. Clear cell sarcoma of soft tissue: a retrospective review and analysis of 31 cases treated at Istituto Ortopedico Rizzoli. Eur J Surg Oncol. 2014;40(5):505-510.

7. Hantschke M, Mentzel T, Rütten A, et al. Cutaneous clear cell sarcoma: a clinicopathologic, immunohistochemical, and molecular analysis of 12 cases emphasizing its distinction from dermal melanoma.Am J Surg Pathol. 2010;34(2):216-222.

8. Feasel PC, Cheah AL, Fritchie K, Winn B, Piliang M, Billings SD. Primary clear cell sarcoma of the head and neck: a case series with review of the literature. J Cutan Pathol. 2016;43(10):838-846.

9. Kiuru M, Hameed M, Busam KJ. Compound clear cell sarcoma misdiagnosed as a Spitz nevus. J Cutan Pathol. 2013;40(11):950-954.

10. Miettinen M, McCue PA, Sarlomo-Rikala M, et al. Sox10--a marker for not only schwannian and melanocytic neoplasms but also myoepithelial cell tumors of soft tissue: a systematic analysis of 5134 tumors. Am J Surg Pathol. 2015;39(6):826-835

11. Karamchandani JR, Nielsen TO, van de Rijn M, West RB. Sox10 and S100 in the diagnosis of softtissue neoplasms. Appl Immunohistochem Mol Morphol. 2012;20(5):445-450

12. Yang $L$, Chen $Y$, Cui $T$, et al. Identification of biomarkers to distinguish clear cell sarcoma from malignant melanoma. Hum Pathol. 2012;43(9): 1463-1470.

13. Mesbah Ardakani N, Thomas $C$, Robinson $C$, et al. Detection of copy number variations in melanocytic lesions utilising array based comparative genomic hybridisation. Pathology. 2017;49(3):285-291.

14. Choi, J. H., \& Ro, J. Y. (2018). Cutaneous spindle cell neoplasms: Pattern-based diagnostic approach. Archives of pathology \& laboratory medicine, 142(8), 958-972.

\section{Figures}




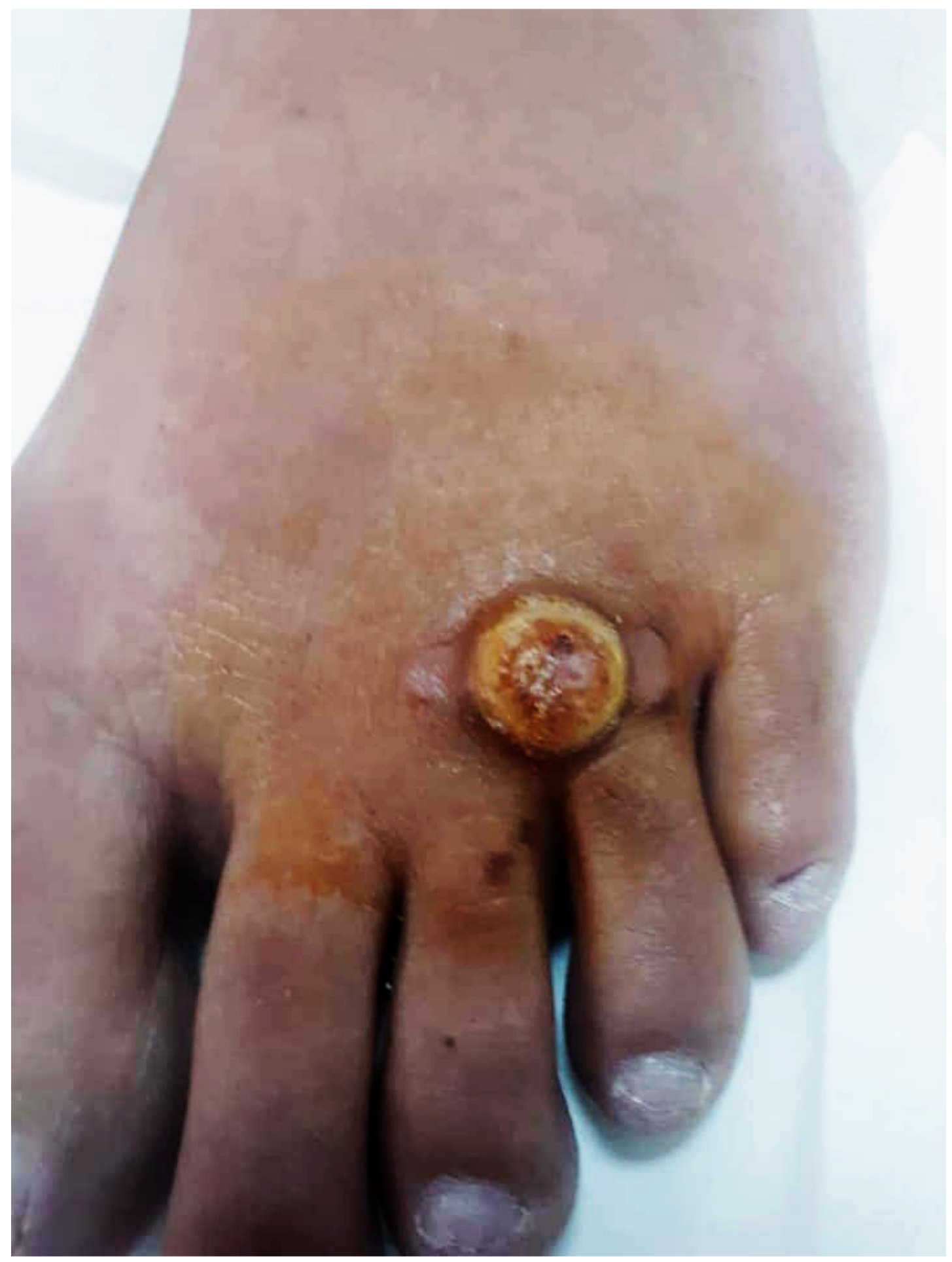

Figure 1

Photography of the $1.5 \mathrm{~cm}$ nodular lesion on the dorsal aspect of the left foot. 


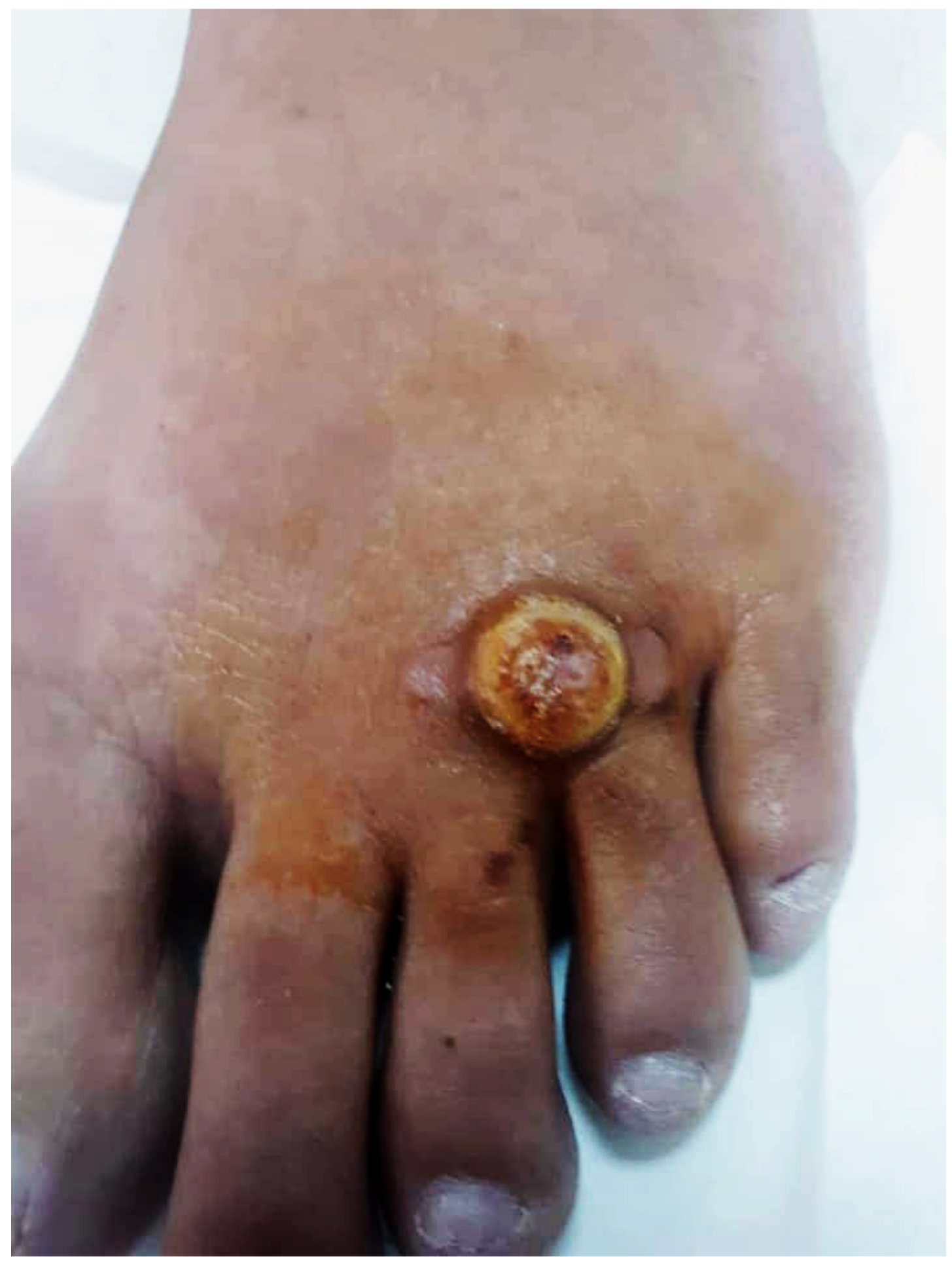

Figure 1

Photography of the $1.5 \mathrm{~cm}$ nodular lesion on the dorsal aspect of the left foot. 


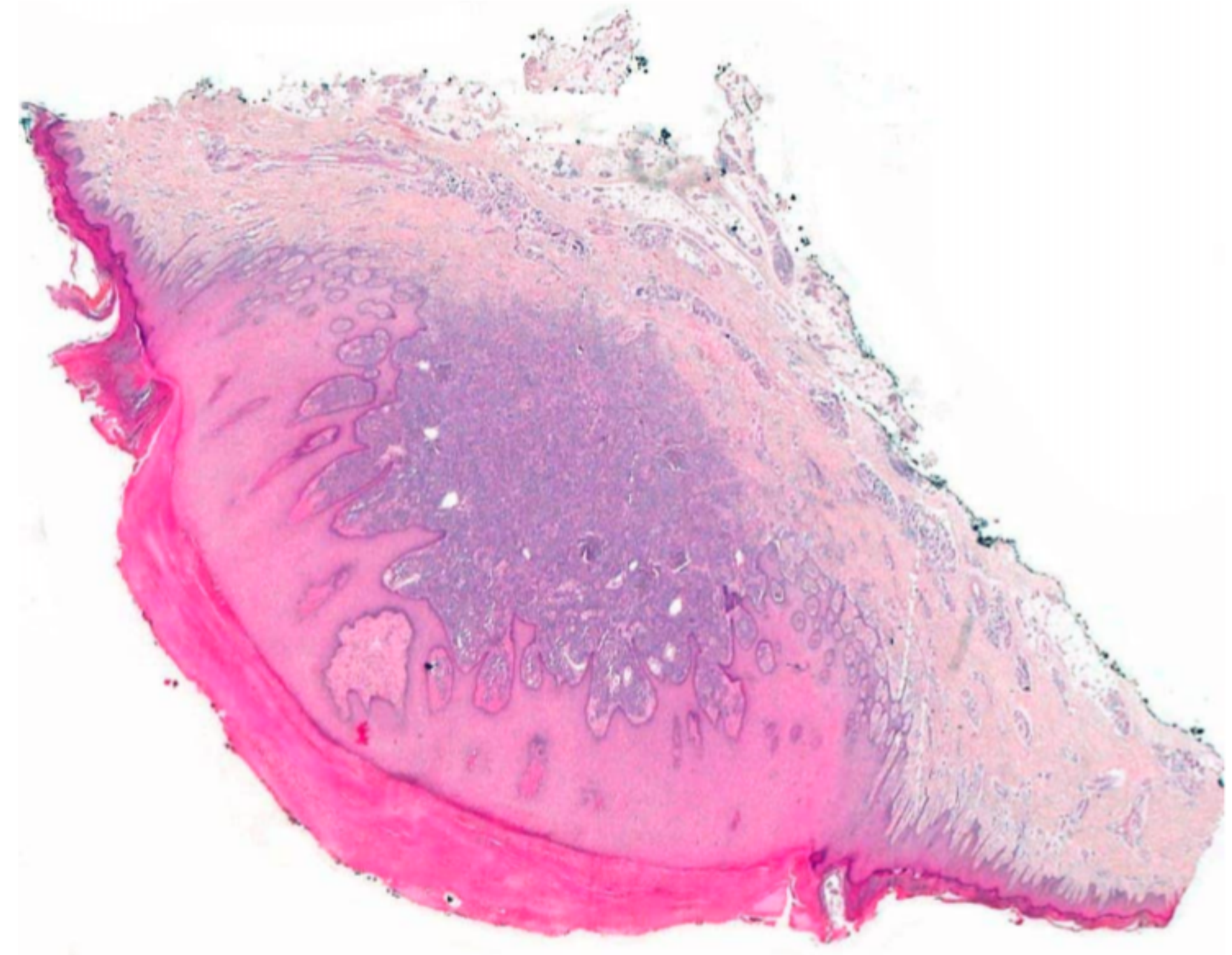

Figure 2

Scanning microphotography showing a well circumscribed dermal symmetrical proliferation. The underlying epidermis is acanthotic and there is non infiltration of the deep dermis. 


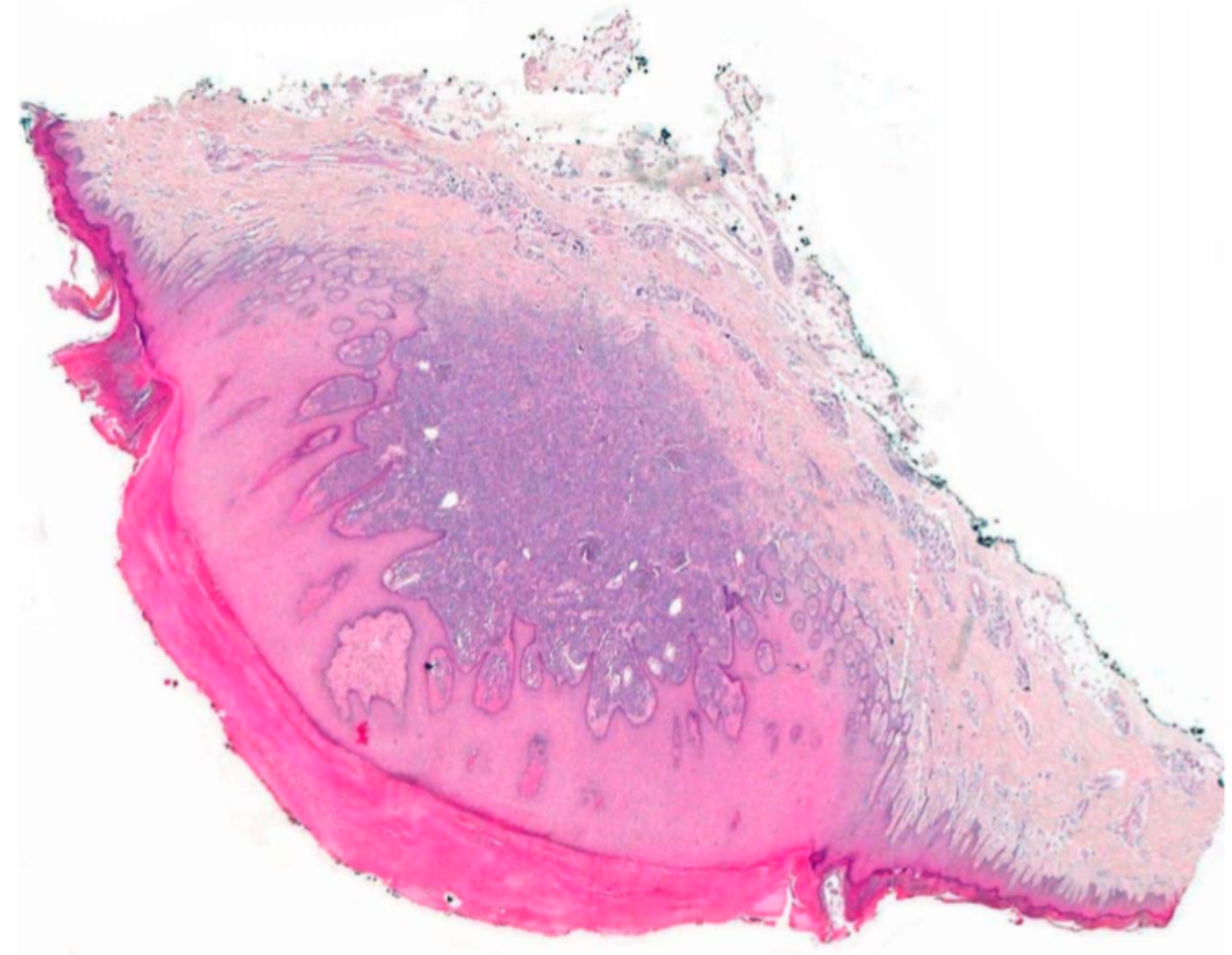

Figure 2

Scanning microphotography showing a well circumscribed dermal symmetrical proliferation. The underlying epidermis is acanthotic and there is non infiltration of the deep dermis. 


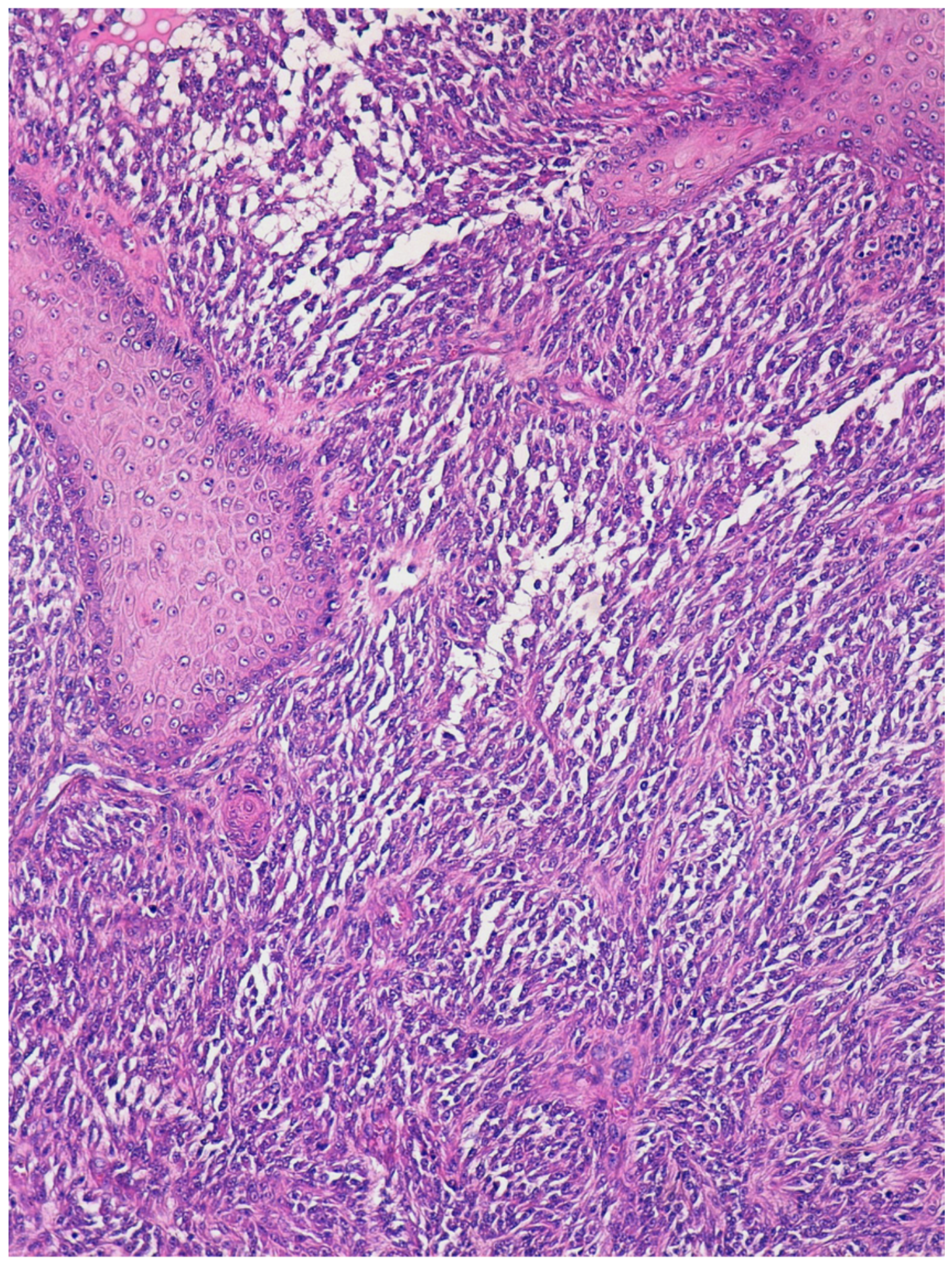

\section{Figure 3}

The proliferation is made of made of spindle cells, organized in short fascicles. (HE, 100X) 


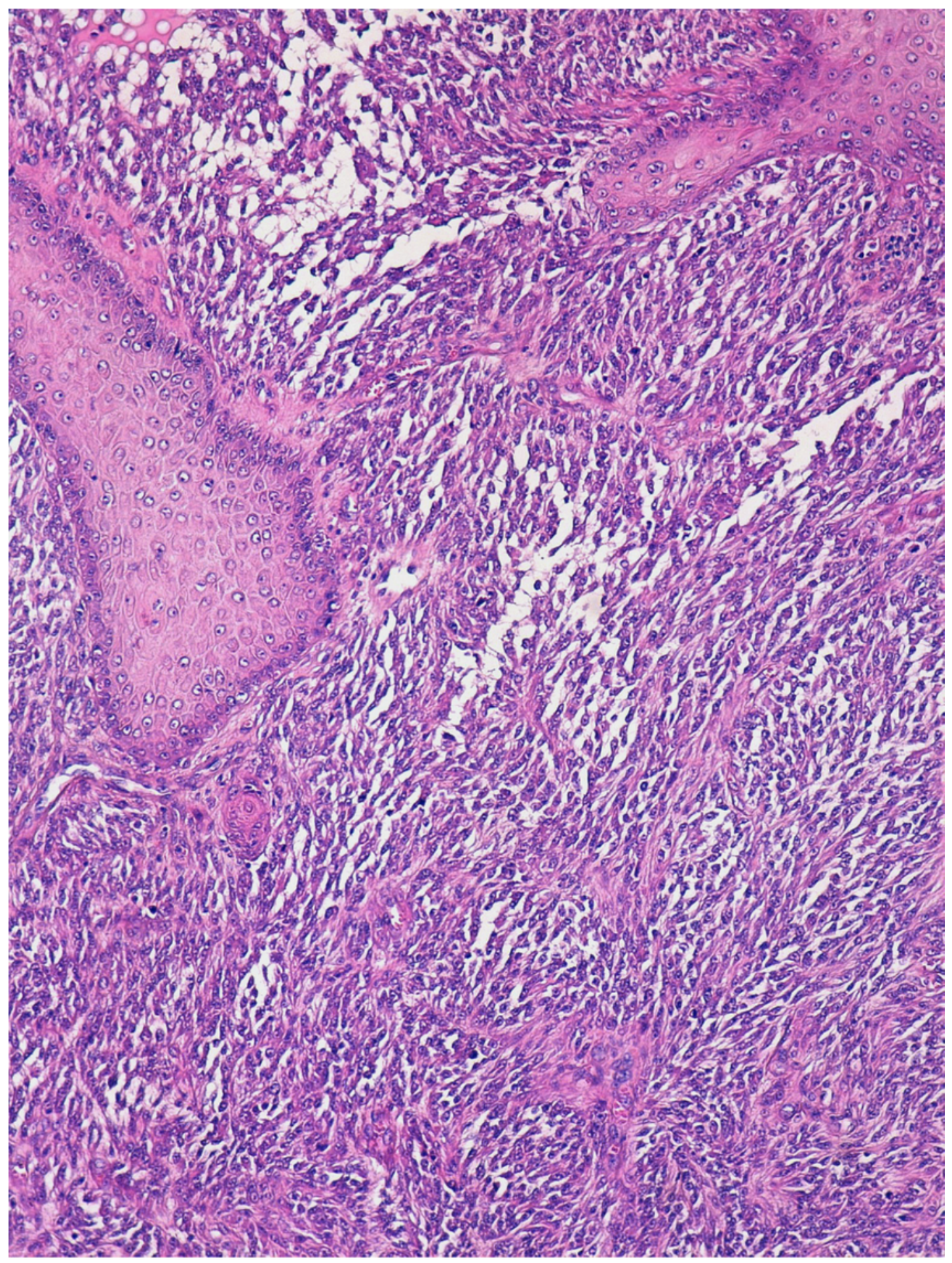

\section{Figure 3}

The proliferation is made of made of spindle cells, organized in short fascicles. (HE, 100X) 


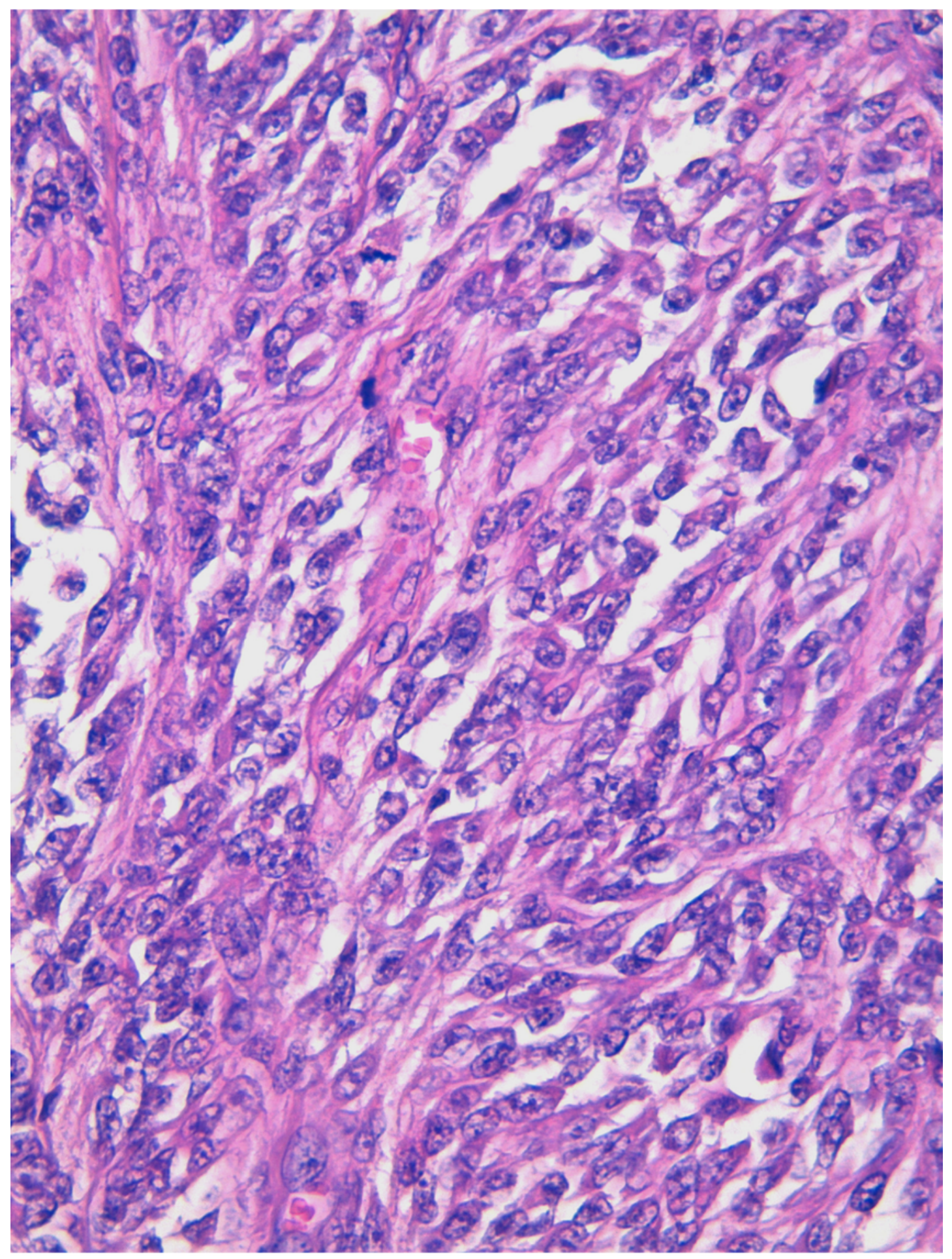

\section{Figure 4}

The neoplastic cells have a spindled shape, an eosinophilic cytoplasm and a vesicular nucleus with prominent nucleolus. (HE, 400X) 


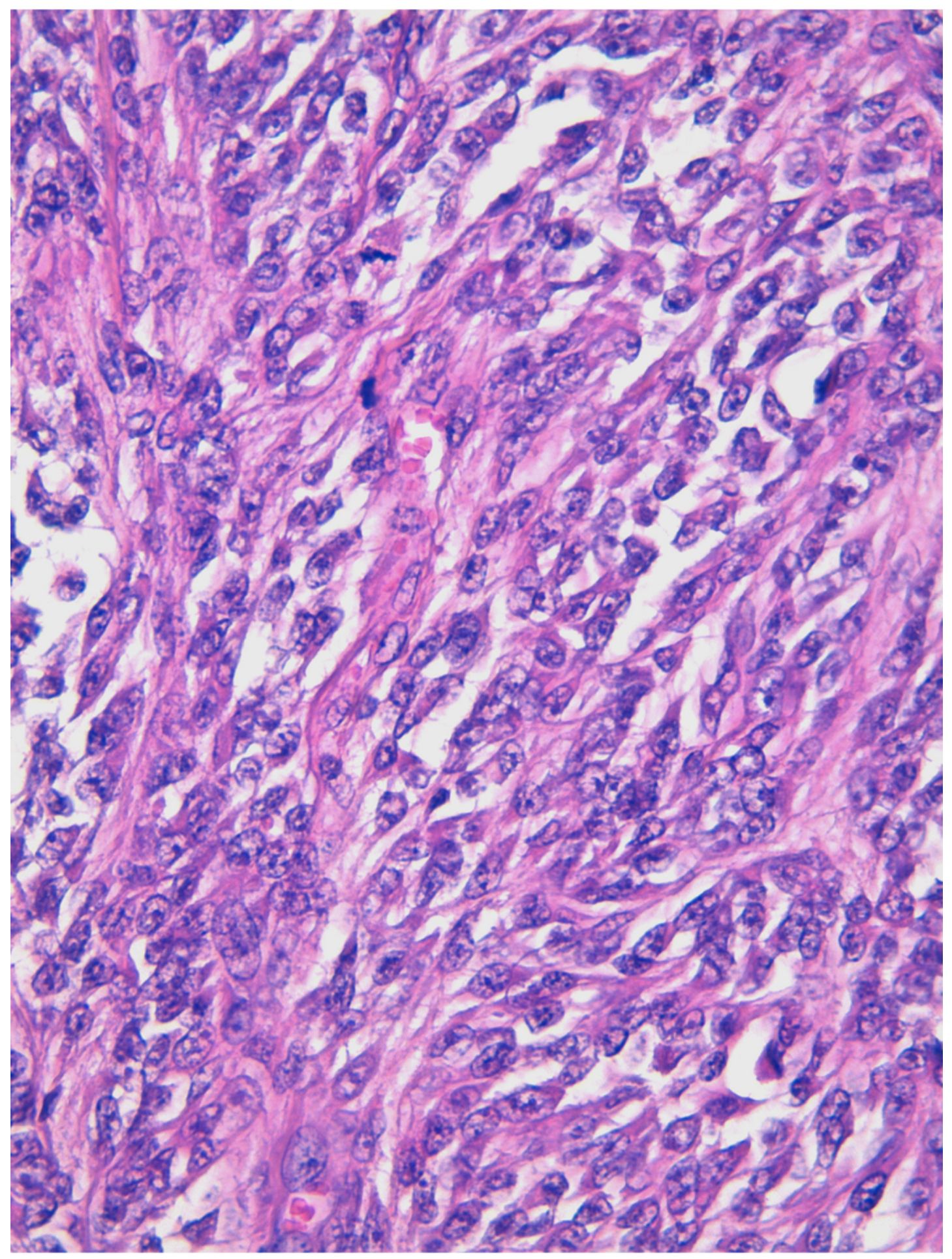

\section{Figure 4}

The neoplastic cells have a spindled shape, an eosinophilic cytoplasm and a vesicular nucleus with prominent nucleolus. (HE, 400X) 


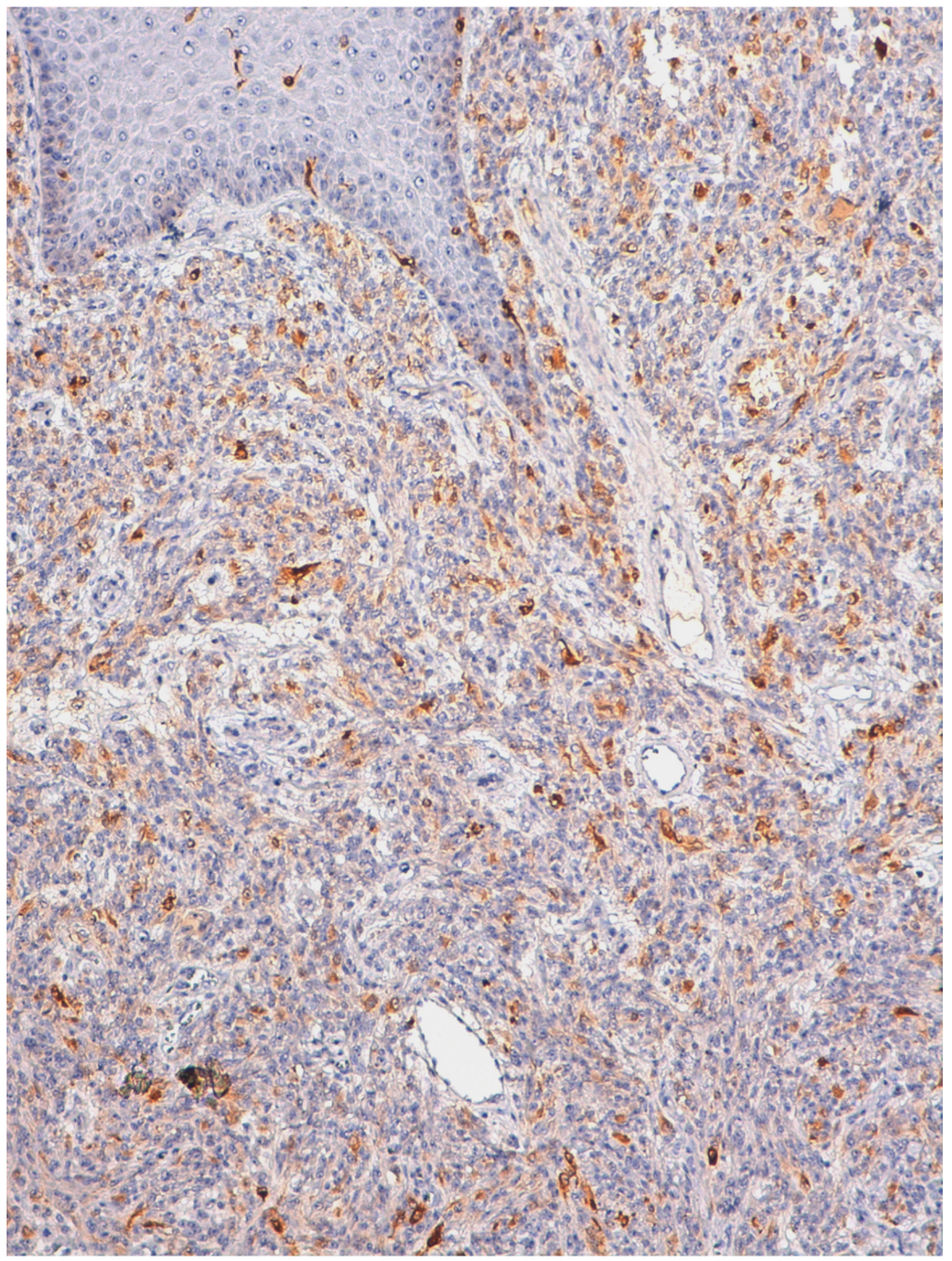

\section{Figure 5}

Microphotography showing expression of Melan A by neoplastic cells 


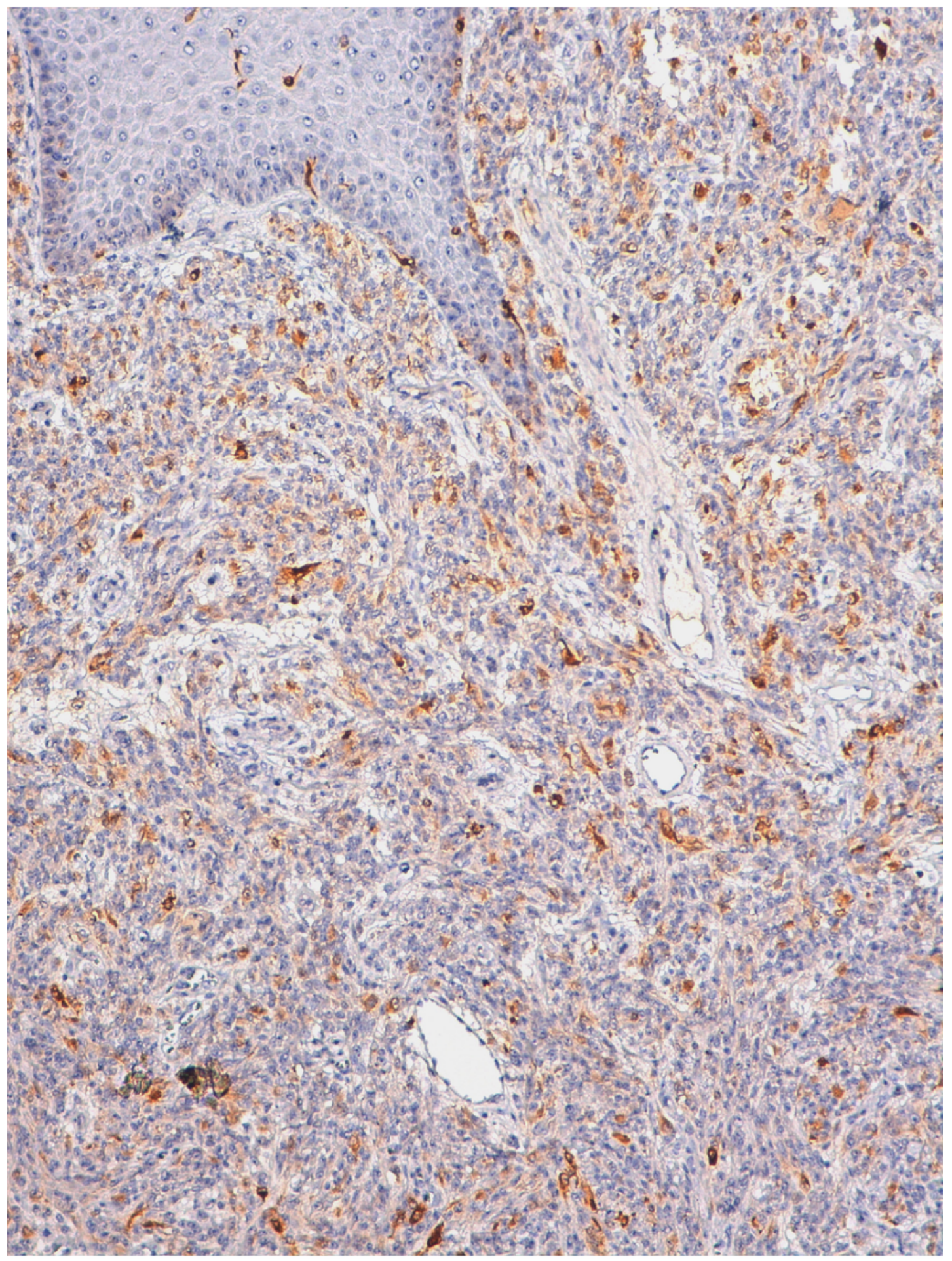

\section{Figure 5}

Microphotography showing expression of Melan A by neoplastic cells 


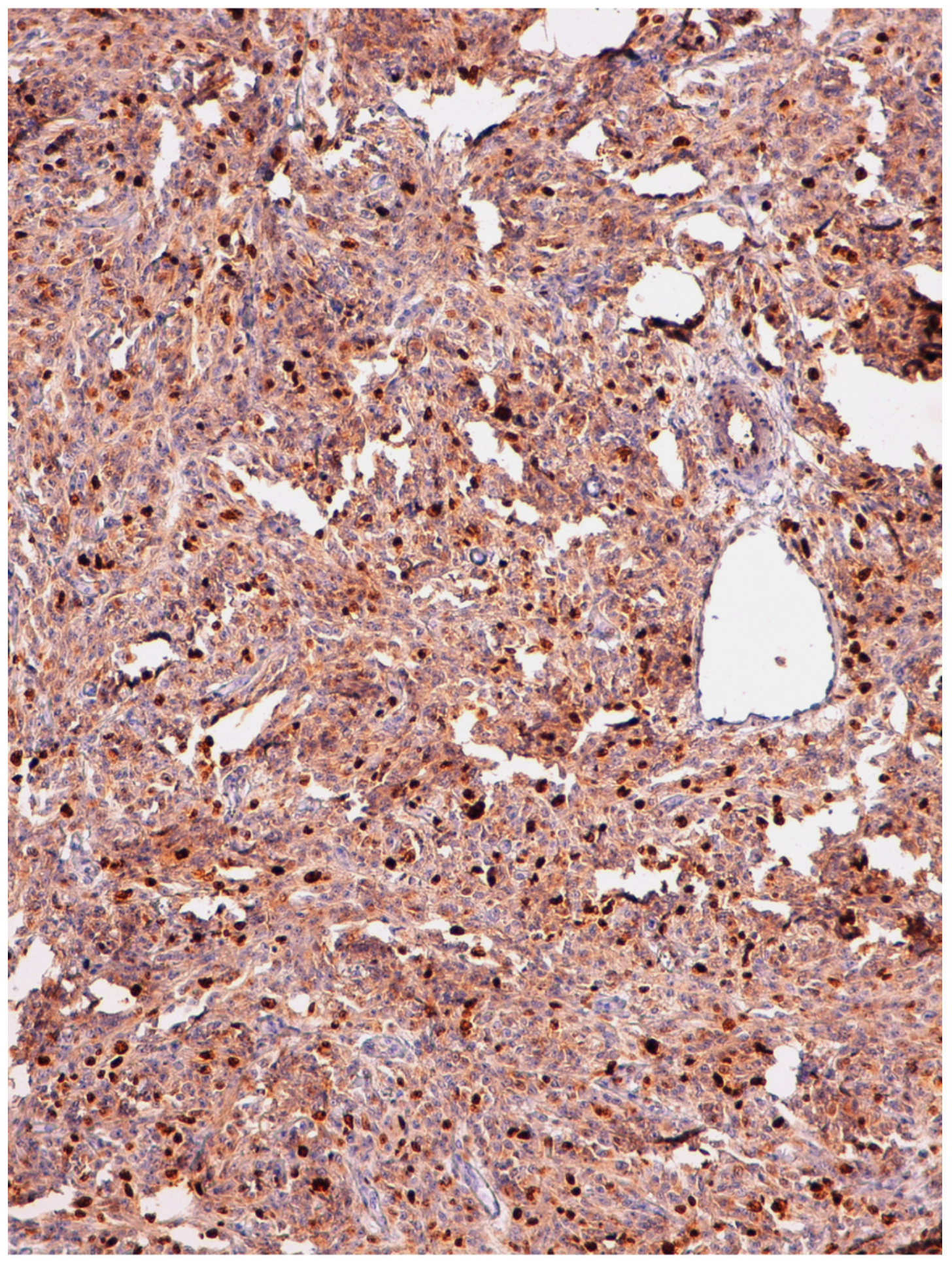

Figure 6

Mitotic activity of the neoplastic cells, evaluated by the anti-Ki-67 was estimated at $20 \%$ 


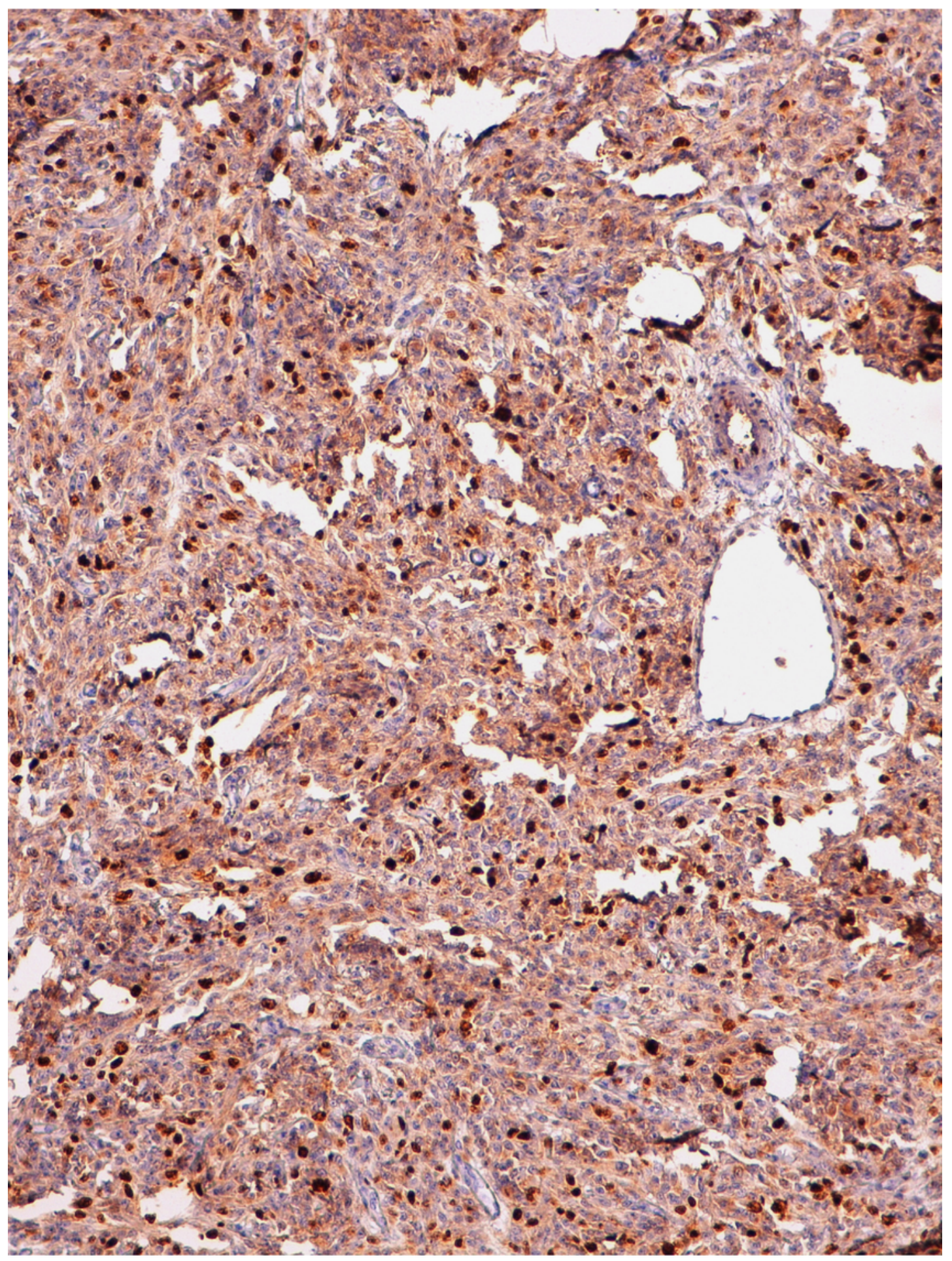

Figure 6

Mitotic activity of the neoplastic cells, evaluated by the anti-Ki-67 was estimated at $20 \%$ 


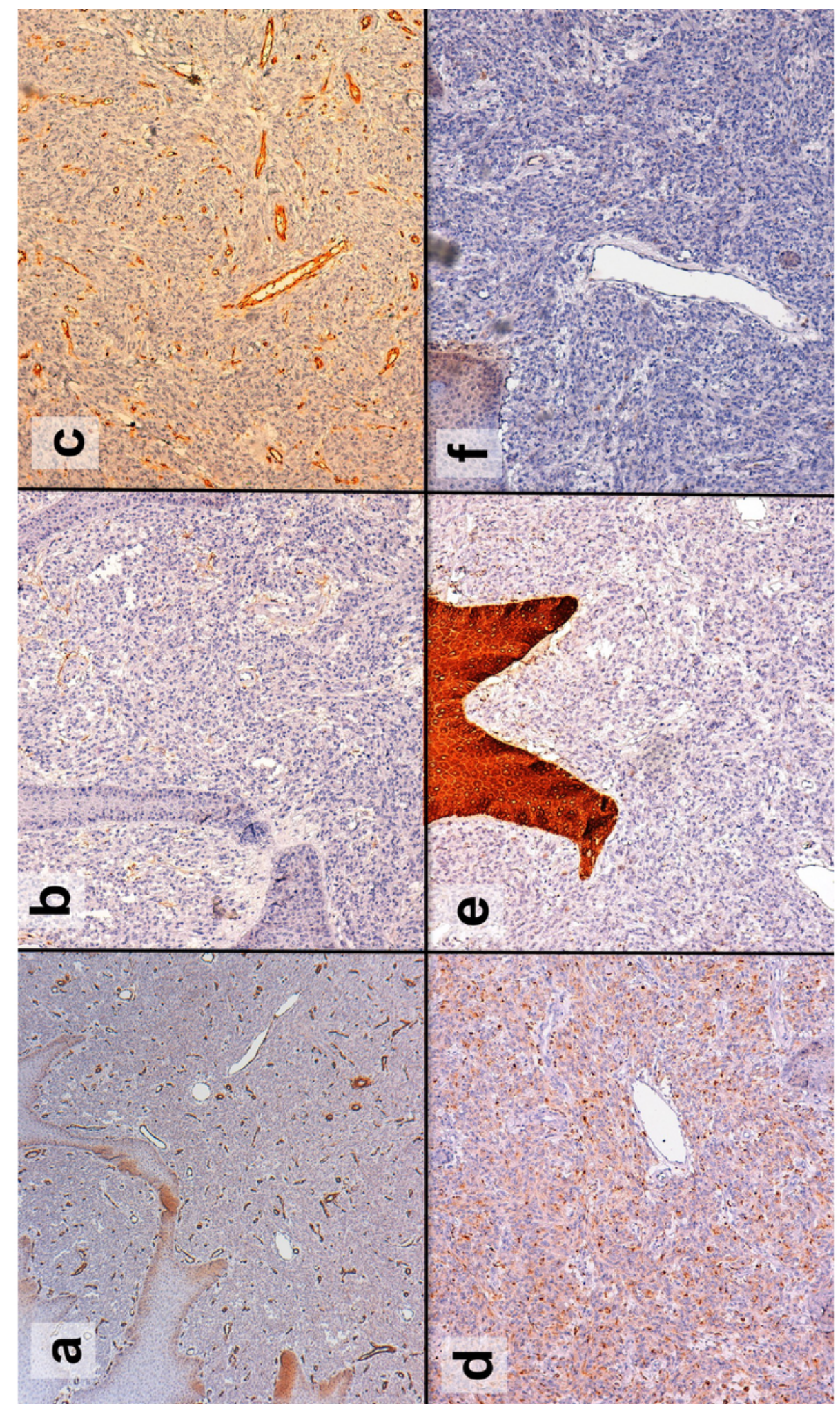

Figure 7

Tumor cells don't express SMA (a), CD10 (b), CD31 (c), CD68 (d), CK5/6 (e), or HMB45 (f) 


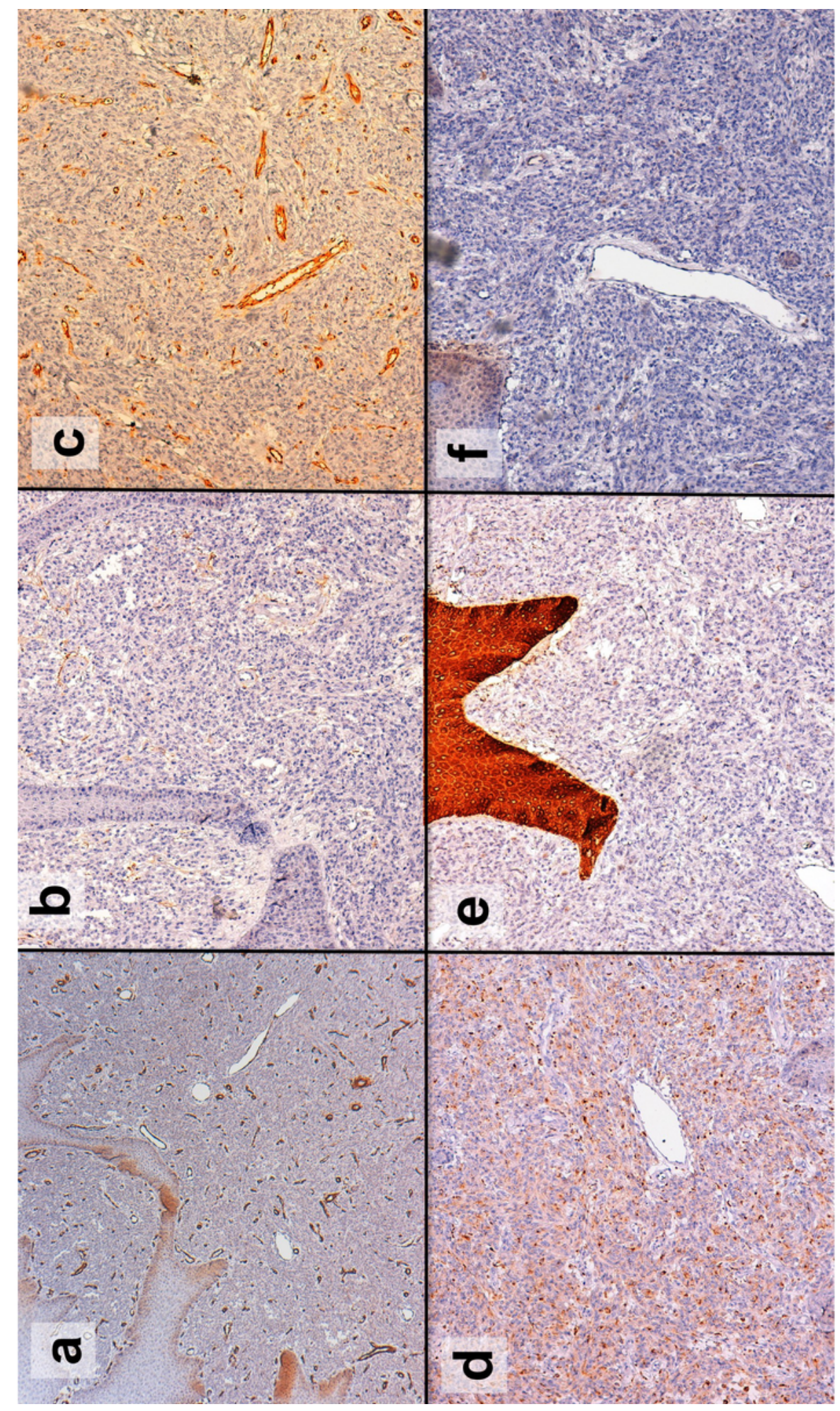

Figure 7

Tumor cells don't express SMA (a), CD10 (b), CD31 (c), CD68 (d), CK5/6 (e), or HMB45 (f)

\section{Supplementary Files}

This is a list of supplementary files associated with this preprint. Click to download. 
- Care.pdf

- Care.pdf

Page 25/25 